$\xi=-$ 国

\title{
Design of Wind/Diesel Generator Micro-Grid Power System in Kano, Nigeria, Using Homer
}

\author{
Nuhu Mohammed*, Ademola Bello Adisa², Mohammed Ahmed Bawa ${ }^{3}$, Habou Dandakuta ${ }^{4}$ \\ 1,2,3,4 Department of Mechanical/Production Engineering, Abubakar Tafawa Balewa University, Bauchi, Nigeria \\ *Corresponding author E-mail: mnuhu@atbu.edu.ng or m.nuhu80@yahoo.com
}

\begin{abstract}
A micro-grid system has been designed using wind/diesel generators power sources. The system is aimed to cater for the electricity demand of Kwankwasiyya city Kano, Nigeria. The city has about 400 housing units with average daily electricity demand of $10000 \mathrm{kWhr}$. The project employed the use of homer, a software that performs Hybrid Optimization Model for Electric Renewables. The most appropriate system architecture was chosen from the optimisation result based on the selection factors set (initial investment cost, total electrical production to site primary demand ratio and so on). A system comprising single wind turbine ( $800 \mathrm{~kW})$, and two generators of 400 $\mathrm{kW}$ and $300 \mathrm{~kW}$ has been selected based on the selection criteria. The electrical output shows that $82 \%$ of the total production will be consumed onsite with the remaining would be sold to the grid. The system has a cost of energy value of $0.279 \mathrm{kWh}$ with net present cost of about $\$ 11,000,000$. The system is economically viable considering the need of reliable power in the region even though, the price of the electricity is higher than what is obtainable from the grid.
\end{abstract}

Keywords: wind; turbine; energy; power; generator

\section{Introduction}

The utilization of wind power can be traced back to thousands of years. The first wind applications were for sailing, ships were used for trading along the coast of Oman and Northwest India, and probably for carrying goods between the first Mesopotamian citystates of Uruk and Ur. [1]. In around $5000 \mathrm{BC}$, wind was used for navigation of a boat on the Nile River [2]. Since then, wind has been used for different applications such as pumping water, milling grains, and other mechanical power applications. Wind usage as an alternative source of power makes it more attractive and appealing. The interest in the exploitation of wind energy for electricity generation has risen towards the end of 20th and at the beginning of the 21 st centuries. It is welcomed by industry, society, and politics as a practical, clean, economical, affordable and environmentally-friendly alternative source of energy [2]. Since then, wind energy has been receiving much attention that leads to the rapid advancement and growth in the wind industry. Wind energy is viewed by many as one of the most encouraging of the renewable energy sources' considering the yearly growth in its installation capacity. It can be rated as the best alternative to conventional power source due to its potentials to meet the rising demands for electricity, and because of its availability across the globe. In addition, most of the other renewable sources are not favourable for large-scale power generation. A prediction shows that wind turbines installations are expected to exceed that of nuclear [1].

Nigeria, a country with more than 182 million people [3] and one of the biggest economy in Africa, faces acute power supply for development and domestic usages. Report shows that the country suffers power outage of about $13 \mathrm{hrs}$ a day [4], which necessitates households and businesses to look for alternatives; supplementary power sources such as diesel generators to cover the shortage sup- ply. One other research shows that Nigerians produce 6,000 MW of electricity using diesel generators in 2012, which is far more than what the power stations across the country generate [5]. The country is among the leading importers of generators in the world. In 2011 alone, about US\$ 10.5 billion was spent on power using diesel generators in the country [5]. The federal Government realised the need for stable power supply in the country, as a result, privatises the power industry in 2013. The Government also has approved a renewable energy master plan in order to encourage diversification of power source since the country is endowed with various sources of energy that include both conventional and renewables. Consequently, the need to decentralise the power generation system in the country can enormously help in achieving stable power. This research presents a design of hybrid wind/diesel generator micro grid power system for Kwankwasiyya city, Kano, having about 400 housing units. The model of the city is as depicted in Fig. 1. The estate is located along Zaria road, latitude $11.901^{\circ}$ and longitude $8.5113^{\circ}$ with an elevation 478 meters [6] few miles away from the central city of Kano.

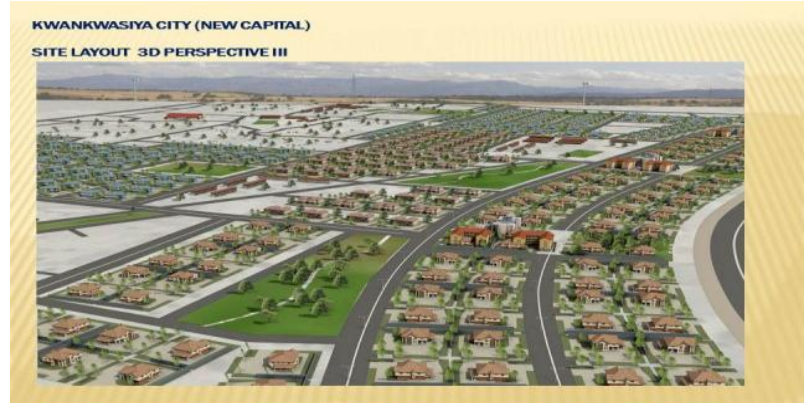

Fig. 1: Kwankwasiyya city, Kano [7] 


\subsection{Wind-diesel generator hybrid system}

Hybrid systems are primarily a combination of two or more different but complementary energy supply sources at a particular site [8]. Wind/diesel generator hybrid system consists of two power generation sources; wind from renewable energy and diesel generator from a conventional source. This type of system can be exploited as a viable alternative for power generation especially in isolated geographical areas without access to grid electricity (typically remote areas) [9], or a place where the power from the grid is not adequate to meet the required energy demand. Electrification using hybrid-micro grid system has become an essential service for development in most areas and most important in regions that are in need of a reliable power generation such as Nigeria.

Wind/Generator power system can be standalone (Autonomous) system or a grid tie designs [10] depending on the factors that necessitate the development of the power system. The autonomous hybrid micro grid systems are more efficient in remote areas. This is because, they save the cost of grid connection, reduce fuel consumption, and provides the daily energy demands in those areas [8]. The grid tie system gives much flexibility and in most times more reliable and economical, especially in countries and regions that grants incentives and feed-in tariff. It is imperative, therefore, to examine the location thoroughly for accurate identification of the most-appropriate connection system that will be more economical when developing a hybrid system. Wind hybrid system design requires careful consideration in selecting the appropriate sizing of the wind turbines. It is thus paramount to investigate the available mean wind speed of the chosen site for proper sizing of the turbine that will produce the required power that can meet the load demand of the area. Hybrid wind/diesel generator power generation systems have a greater potential and advantages providing energy supply for remote communities and facilities when compared to the traditional diesel system alone. It can give many rewards that include saving fuel, cutting carbon emission, reduction in maintenance cost and being more environmentally-friendly [11]. Integration of renewable energy systems provides an excellent opportunity for electricity decentralization at the same time offers energy security to both rural and urban citizens.

\subsection{Homer}

Homer software is designed to perform three principal tasks: simulation, optimization, and sensitivity analysis. During the simulation, the software models the performance of a particular micro power system configuration on an hourly basis of the entire year to determine its technical feasibility and life-cycle cost. In the process of optimization, homer simulates many different system configurations to determine the best configuration that meets the technical constraints at the lowest life-cycle cost. When performing sensitivity analysis, the software executes multiple optimizations for a range of assumptions input to find out the effects of uncertainty or changes in the inputs of the model system [12].

Figure 2 shows the link that exists between the three homer principal tasks, simulation, optimization, and sensitivity analysis. The depiction shows that the optimization oval encircles the simulation oval indicating that, for any single optimisation, multiple simulations can be performed. Likewise, the sensitivity analysis oval encloses the optimization oval implying that for any particular (single) sensitivity analysis, there are multiple optimizations to occur.

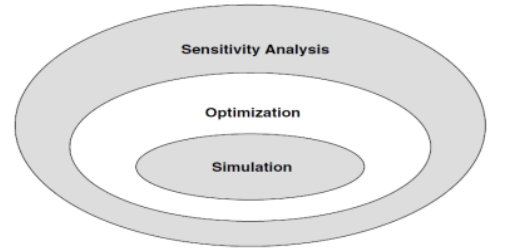

Fig. 2: Conceptual relationship between Simulation, Optimization, and Sensitivity Analysis [12]
The purpose of the optimization is to determine the optimal value of the input variables over which the system modeller has control. These variables may include the components that makeup the system as well as the quantity or size of these components. The sensitivity analysis process helps the modeller to examine the effects of uncertainty or changes in the variables of which the designer has no control, such as the average wind speed or the future fuel price [12]

\section{Method}

\subsection{Extractable power from wind}

The theoretical formula for determining power output indicates that the wind power is proportional to the third power of the wind speed as presented in equation (1).

$$
\mathrm{P}=1 / 2 \rho \mathrm{AV}^{3}
$$

Where: $\rho=$ density of air, $A=$ swept area of the turbine, $V=$ wind mean velocity, and $\mathrm{P}=$ available power

The maximum theoretical value of the wind turbine performance coefficient is 0.593 known as the Betz limit. The theoretical available power in the moving wind given in equation (1) is unachievable by rotor due to wind velocity drop during energy extraction and some other losses. As a result, the actual extractable power by the rotor blades becomes the difference between upstream and the downstream wind powers. This relation is expressed as a function of the turbine power coefficient (Cp) as shown in equation (2) [13]

$P_{o}=1 / 2 \rho A V^{3} C_{p}$

\subsection{Design inputs}

The input parameters for the design are:

\subsubsection{Wind resource}

Fig. 3 shows the monthly wind resource as well as the time series wind speed of the location respectively. The annual average wind speed was found to be $4.6 \mathrm{~m} / \mathrm{s}$ @ $10 \mathrm{~m}$ height.

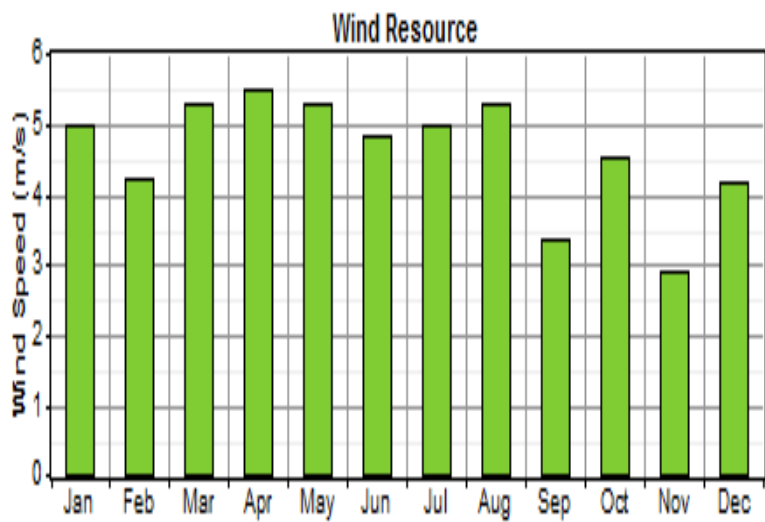

Fig. 3: Wind Resource @10m Height

The Weibull frequency distribution gives the overview of wind speed variation of the location as depicted in Fig. 4, where $c$ represent the scale parameter, a factor related to the annual mean wind speed, and $\mathrm{k}$ is the dimensionless shape parameter, a factor that describes the variation about the mean. 


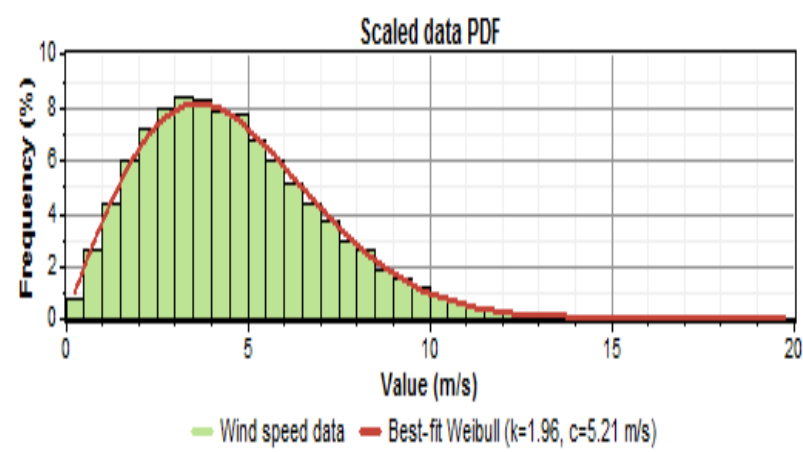

Fig. 4: Weibull Frequency distribution

Further analysis of the wind regime at the location was conducted using WindPro. The prevalent wind direction was obtained in form of frequency distribution as depicted in Fig. 5 [13]. More details of the wind resource study can be obtained in [13].
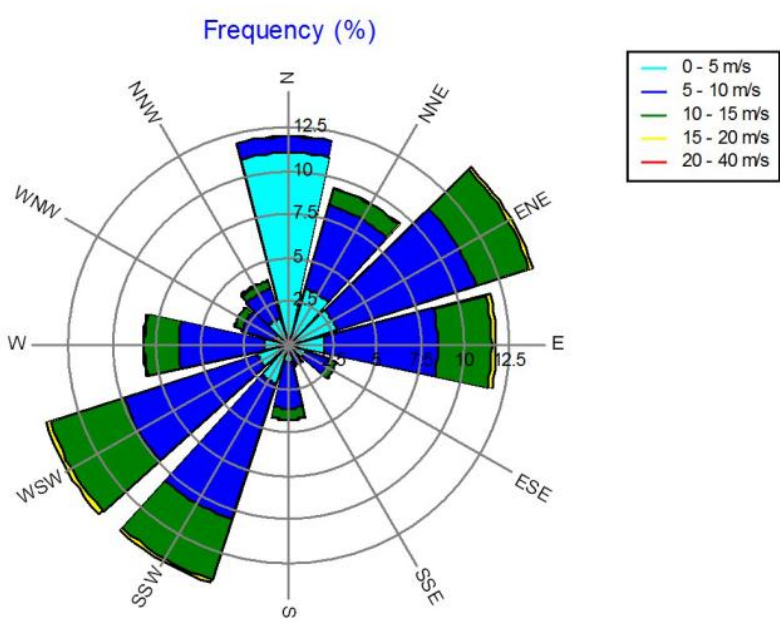

Fig. 5: Wind Speed Frequency Distribution Rose

\subsubsection{Load demand}

The electrical demand that a power system must meet at a specific time is referred to as Primary Load. This load includes that of lightings, household appliances, TV, radios, computers. The primary load for this project has been estimated based on the historical load demand trend in the country [4]. Fig. 6 shows the average hourly daily load profile from 0:00 to 24:00 used in this project.

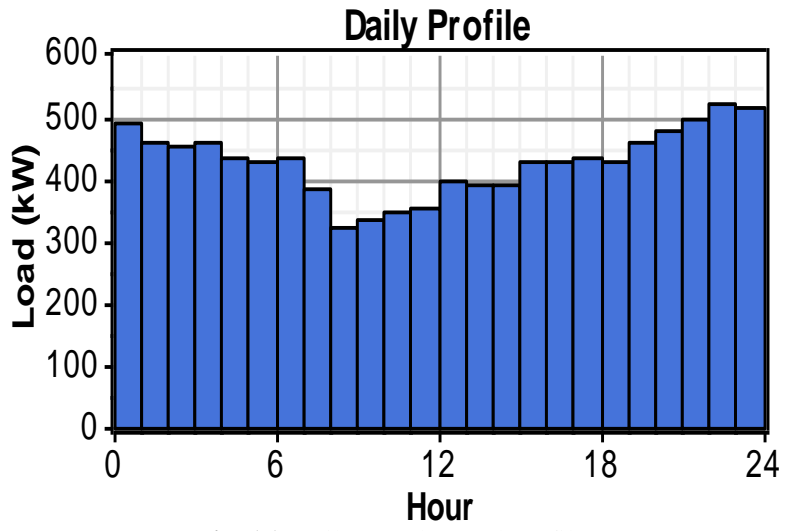

Fig. 16: Daily Hourly Load Profile

The baseline load and the scaled load were calculated by the homer based on the daily load profile inputted as depicted in Table 1.
Table 1: Load Parameters

\begin{tabular}{lll} 
& Baseline & Scaled \\
\hline Average $(\mathrm{kWh} /$ day) & 10,240 & 10,240 \\
Average $(\mathrm{kW})$ & 427 & 427 \\
Peak $(\mathrm{kW})$ & 874 & 874 \\
Load factor & 0.488 & 0.488 \\
\hline
\end{tabular}

The Baseline data is an annual time series that represents the average electric demand $(\mathrm{kW})$, whereas, the scaled data is the multiplication of each of the baseline data values by a common factor which the homer does. The default value for the scaled annual average is the baseline annual average and when the two values are equal, the scaled data and baseline are identical [12]. The load factor is calculated using the expression as in (3).

\section{Load factor $=($ Average Power in $(\mathrm{kW})) /($ Peak Power in $(\mathrm{kW}))$}

The calculated values in Table 1 indicate that the micro-grid system under design must serve an average load of $10,240 \mathrm{kWh} /$ day for the entire life-cycle. The site has an average power requirement of $427 \mathrm{~kW}$ and a peak power demand of $874 \mathrm{~kW}$. Therefore, the size of the micro-grid system was determined based on these values.

The average seasonal load demand of the project site calculated by the homer is as shown in Fig. 7. The values indicate the estimated average load that must be served every month throughout the system lifetime.

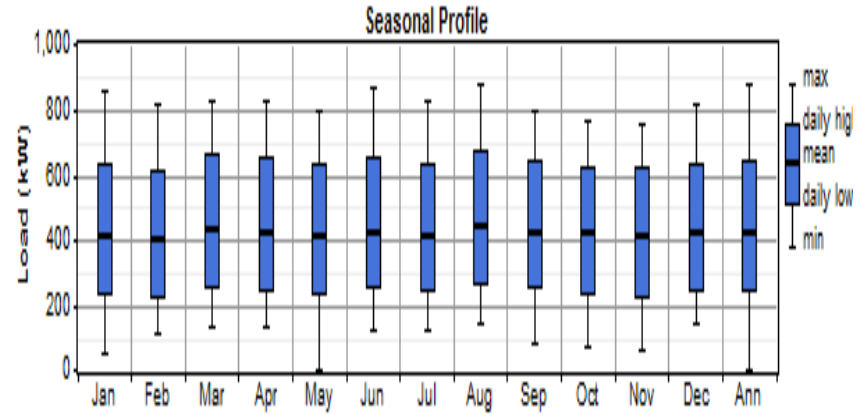

Fig. 7: Average Seasonal Load Demand

The hourly distribution of the load demand modelled by the homer for the whole year is as shown in Fig. 8. The distribution presents the load demand expected every hour from January to December for the entire power system duration with the colours representing the demand at any particular hour of the day.

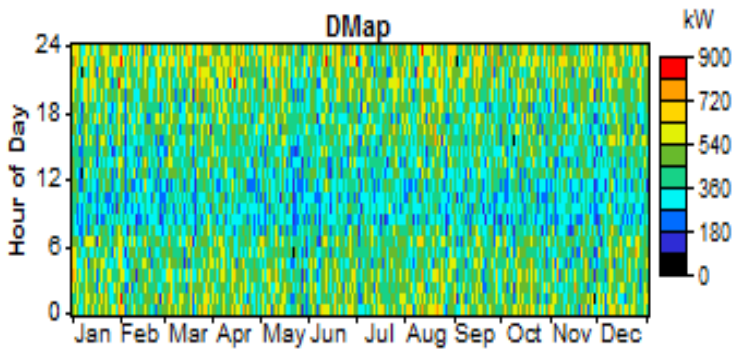

Fig. 8: Hourly Load Demand distribution for one Year

\subsubsection{Grid rate}

The Grid rates are the prices associated with buying electricity from the grid and/or selling electricity to the grid (Lambert, 2010). With grid-connected system, it is possible to buy electricity from the grid when necessary, i.e. when there is a short fall in the supply by the micro-power system. Table 2 gives a description and the prices of the rate variables used in this simulation. 
Table 2: Grid Price Input

\begin{tabular}{lll}
\hline Variable & \multicolumn{1}{c}{ Tescription } & $\begin{array}{l}\text { Price in } \\
\$ / \mathrm{kWh}\end{array}$ \\
\hline Power price & $\begin{array}{l}\text { Cost associated with buying power } \\
\text { from the grid, in } \$ / \mathrm{kWh}\end{array}$ & 0 \\
Sellback rate & $\begin{array}{l}\text { The price that the utility pays for } \\
\text { power sell to the grid } \\
\text { The monthly fee charged by the util- } \\
\text { ity on the monthly peak demand. }\end{array}$ & 0.05 \\
\hline
\end{tabular}

Non-purchase of electricity from the grid was considered for the system design, because the power from the grid is unreliable with regards to time of the outage. This problem makes it very difficult to consider the purchase from the grid when designing the power system. As such, the system was modelled to meet the load demand of the site and sell back any excess production to the grid.

\subsection{Optimisation variables}

Various sizes of wind turbine and generators were considered as the optimization variables as shown in Table 3. Four options of wind turbines combined with generator of different sizes were optimised.

\begin{tabular}{llccccc}
\multicolumn{7}{c}{ Table 3: Design components } \\
\hline & $\begin{array}{l}\text { Turbine } \\
\text { (Quantity) }\end{array}$ & E-53 & $\begin{array}{l}\text { GEN } \\
(\mathrm{kW})\end{array}$ & $\begin{array}{l}\text { Gen } \\
(\mathrm{kW})\end{array}$ & Grid & \\
\hline 1 & 1 & & 400 & 200 & 0 \\
2 & 2 & & 500 & 300 & 0 \\
3 & 3 & 600 & 400 & 0 \\
4 & - & 800 & 500 & 0 \\
5 & - & - & 600 & 0 \\
\hline
\end{tabular}

A fuel price of $1.24 \$ / \mathrm{L}$ was considered as the baseline diesel price alongside two values of $1.7 \$ / \mathrm{L}$ and $0.9 \$ / \mathrm{L}$ for sensitivity analysis. The system was assumed to have 20 years project life at a discounted rate of $10 \%$, and a generator operating hours of 30000 .

\subsubsection{Cost of components}

The costs variables of the components considered are:

\begin{tabular}{lllc}
\multicolumn{4}{c}{ Table 4: Cost of components } \\
\hline Components & $\begin{array}{l}\text { capital cost in } \\
\$ / \mathrm{kW}\end{array}$ & $\begin{array}{l}\text { Cost of Re- } \\
\text { placement in } \\
\$ / \mathrm{kW}\end{array}$ & $\begin{array}{c}\text { O\&M cost } \\
\$\end{array}$ \\
\hline $\begin{array}{l}\text { Wind Turbine } \\
\text { Diesel Gener- } \\
\text { ator }\end{array}$ & 2500 & 2250 & 30000 per yr. \\
& 250 & 220 & 0.5 per hr. \\
\hline
\end{tabular}

\subsection{Sensitivity analysis variables}

Wind speed and the fuel cost are the two primary variables, but only the fuel cost was considered in the modelling keeping the wind speed fix as presented in Table 5. Although wind speed is supposed to be investigated considering its tendencies of variation with time, but this research limits its sensitivity variable to fuel price alone. It can be seen that the wind speed is within an average between lower values and the higher values of which the variations in both values is of less consequence. The price of diesel in Nigeria varies immensely from year to year over the past 20 years. The baseline fuel cost was based on average price from 2014 to 2018.

Table 5: Sensitivity Values

\begin{tabular}{llll}
\hline Variables & $\begin{array}{l}\text { Baseline } \\
\text { case Value }\end{array}$ & $\begin{array}{l}\text { Sensitivity } \\
\text { case 1 }\end{array}$ & $\begin{array}{l}\text { Sensitivity } \\
\text { case 2 }\end{array}$ \\
\hline $\begin{array}{l}\text { Wind speed }(\mathrm{m} / \mathrm{s}) \\
\begin{array}{l}\text { @ } 10 \mathrm{~m} \text { height } \\
\text { Cost of Fuel (\$/L) }\end{array}\end{array}$ & 4.67 & 4.67 & 4.67 \\
\hline
\end{tabular}

\subsection{Other considerations}

The load profile is assumed to be the same (regardless of weekdays or weekends) throughout the days of the year. This assumption was made based on the fact that the load profile is already averaged from the measured weekdays and weekend load profile. The designed system cannot draw power from the grid because the grid is not reliable.

\section{Result}

\subsection{Optimisation result}

The modelling involves 80 simulations with 50 feasible solutions being found from the optimization. Homer arranges optimised results based on their net present cost (NPC) values with the best feasible system architecture on top. The NPC represents the total value of all revenues earned throughout the entire life- cycle of operation of the system. The cost of electricity (COE) is the overall cost of energy that the system will be selling which homer calculates based on the system initial capital cost and the yearly operations and maintenance cost (including fuel cost).

\subsubsection{Baseline case}

System with one turbine option has less wind penetration which makes it simple and more reliable than the one with two and three options as depicted in Fig. 9. The system though has a fairer total electrical production to site primary load consumption ratio, but its cost of energy is higher than that of those two options. The system initial cost is lower than that of option one and two.

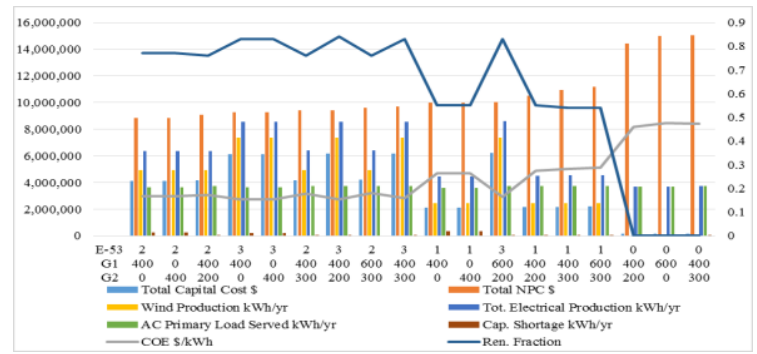

Fig. 9: Baseline optimization result @ 1.24\$/L

\subsubsection{Sensitivity case 1 result}

A higher value of fuel price affects the COE and NPC of the whole system. The system may therefore be cheaper when the cost of fuel fall and would become expensive when the fuel prices goes up as seen from the sensitivity graphs. The economic parameters varied when the sensitivity analysis on the cost of fuel was carried out as can be seen in Fig.10. The result shows a rise in the cost of electricity (COE) and other costs at a fuel price of $1.7 \$ / \mathrm{L}$ as compared to that of the baseline values Figure 9.

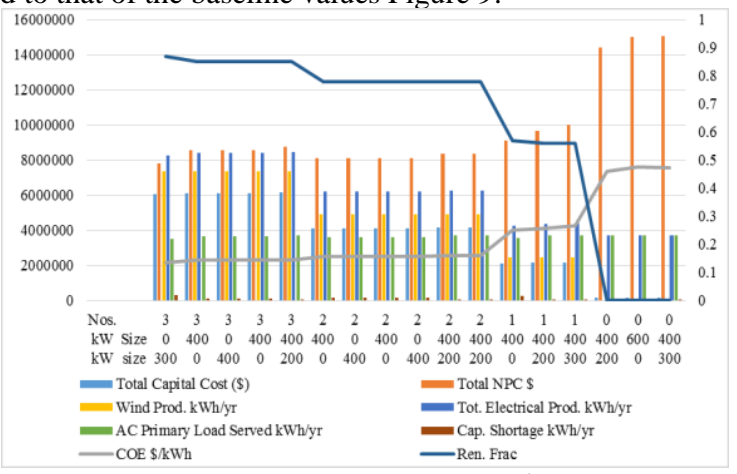

Fig. 10: sensitivity result @ 1.7\$/L 


\subsubsection{Sensitivity case 2 result}

When the fuel price falls to $0.9 \$ / \mathrm{L}$, all the economic variables also go down, making the system cheaper and more attractive than the baseline economic values as can be seen in Fig. 11.

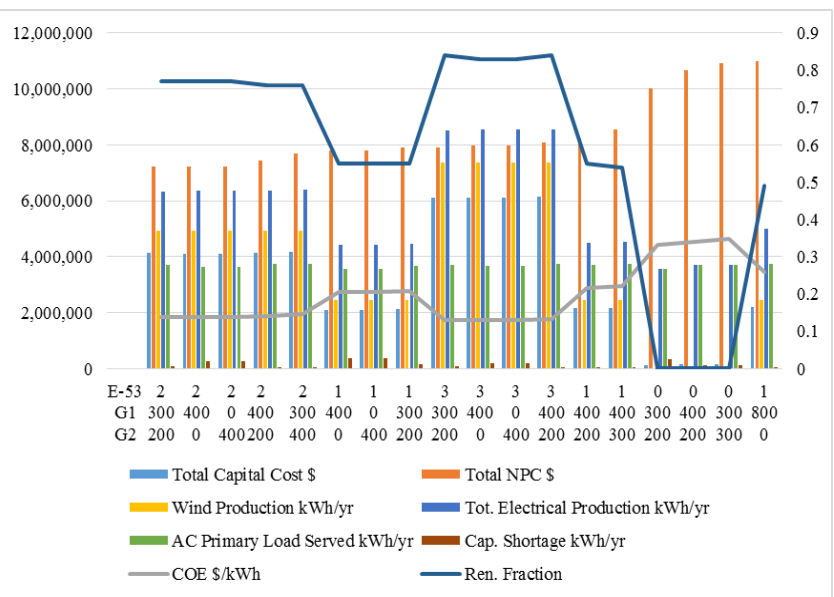

Fig. 11: Sensitivity result @ $0.9 \$ / L$

\subsection{Best system selection}

The wind turbine was modelled alongside two generator sets (generator 1 and generator 2) of different sizes to select the most appropriate system. The considered size options are: $0 \mathrm{~kW}$ wind turbine, single wind turbine $(800 \mathrm{~kW})$, two wind turbines $(1600$ $\mathrm{kW})$, and three wind turbines $(2400 \mathrm{~kW})$. Even though homer displays optimisation result (feasible solutions) based on their NPC and COE, the selection of the best system for this research deviate from this analogy. This deviation is because other factors such as simplicity of the power system, wind penetration, low initial cost of the system, and total energy production to site load demand ratio were put into consideration. [15] reports from [16] that 'high penetration of wind energy creates stability problem, and possible blackouts', as well as creating 'more stress on breaker, transmission line, bus bar at the time of fault occurs, due to high penetration of wind energy resources' [15]. Also, 'electric utility system planners and operators are concerned that variations in wind plant output may increase the operating costs of the system' [17]. As such, a system with single turbine has been chosen as the most appropriate system because is simpler, and easy to maintain when compared to system with two and three turbines.

\subsubsection{System architecture}

The system architecture uses AC bus system. Fig. 12 shows the schematic diagram of the integrated components. Both the wind turbine and the Generators dispatch their power directly to the primary load and the excess power was sold to grid according to the design.

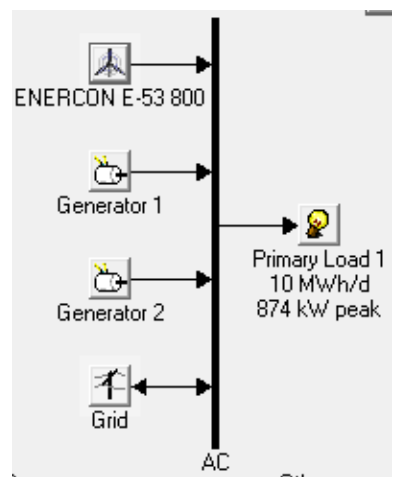

Fig.12: System architecture diagram

\subsection{Total electrical production}

Table 6 and 7 show the total electric production and the output consumption respectively for the baseline case.

Table 6: Total electrical production

\begin{tabular}{|c|c|c|c|}
\hline Production & Capacity $(\mathrm{kW})$ & kWh/yr. & $\%$ \\
\hline $\begin{array}{l}\text { Wind turbine } \\
\text { ( ENERCON E- } \\
\text { 53) }\end{array}$ & 800 & $2,455,682$ & 54 \\
\hline Generator 1 & 400 & $1,392,472$ & 31 \\
\hline Generator 2 & 300 & 695,445 & 15 \\
\hline Grid purchases & 0 & 0 & 0 \\
\hline Total & & $4,543,599$ & 100 \\
\hline
\end{tabular}

Table 7: Output consumption

\begin{tabular}{lll}
\hline Consumption & $\mathrm{kWh} / \mathrm{yr}$. & $\%$ \\
\hline AC primary load & $3,736,067$ & 82 \\
Grid sales & 807,543 & 18 \\
Total & $4,543,610$ & 100 \\
\hline
\end{tabular}

It can be seen that the load demand will consume $82 \%$ of the generation, while sales to the grid amounts to $18 \%$

\subsubsection{AC wind turbine output}

The wind power parameters for the selection is shown in Table 8, having cost of electricity $0.108 \$ / \mathrm{kWh}$.

\begin{tabular}{lll}
\multicolumn{3}{c}{ Table 8: Turbine output } \\
\hline Quantity & Value & Units \\
\hline Total rated capacity & 800 & $\mathrm{~kW}$ \\
Total production & $2,455,682$ & $\mathrm{kWh} / \mathrm{yr}$ \\
Levelized cost & 0.108 & $\$ / \mathrm{kWh}$ \\
Maximum output & 810 & $\mathrm{~kW}$ \\
Mean output & 280 & $\mathrm{~kW}$ \\
Minimum output & 0 & $\mathrm{~kW}$ \\
Capacity factor & 35.0 & $\%$ \\
Hours of operation & 8,760 & $\mathrm{hr} / \mathrm{yr}$ \\
\hline
\end{tabular}

The monthly power generation from the wind turbine follows the pattern shown in Fig. 13.

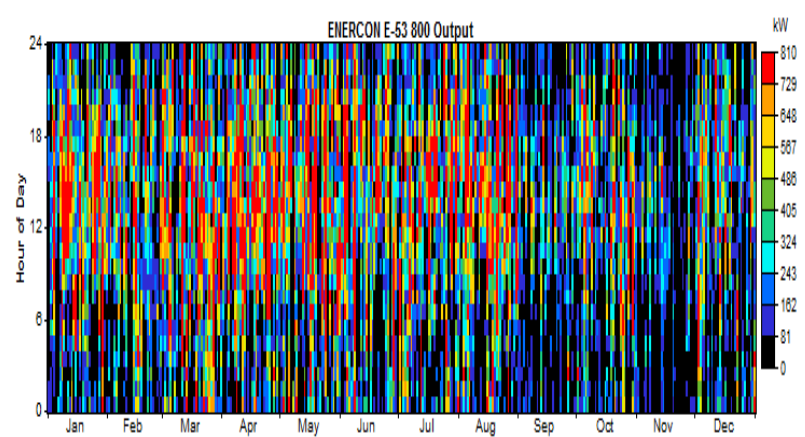

Fig. 213: Turbine production pattern

\subsubsection{Generators output}

The generators power production parameters (Table 9) and Table 10 depicted fuel consumption by each of the generator over a year.

Table 9: Generators Parameters

\begin{tabular}{llll}
\hline & Units & $\begin{array}{l}\text { Gen1 } \\
\text { Value }\end{array}$ & $\begin{array}{l}\text { Gen2 } \\
\text { Value }\end{array}$ \\
\hline Electrical production & $\mathrm{kWh} / \mathrm{yr}$. & $1,392,472$ & 695,445 \\
Mean electrical output & $\mathrm{kW}$ & 296 & 112 \\
Min. electrical output & $\mathrm{kW}$ & 120 & 90.0 \\
Max. electrical output & $\mathrm{kW}$ & 400 & 300 \\
Hours of operation & $\mathrm{hr} / \mathrm{yr}$. & 4,708 & 6,232 \\
Number of starts & $\mathrm{starts} / \mathrm{yr}$. & 1,030 & 1,564 \\
Operational life & $\mathrm{yr}$. & 3.19 & 2.41 \\
Capacity factor & $\%$ & 39.7 & 26.5 \\
\hline
\end{tabular}




\begin{tabular}{|c|c|c|c|}
\hline $\begin{array}{l}\text { Fixed generation cost } \\
\text { Marginal generation cost }\end{array}$ & $\begin{array}{l}\$ / \mathrm{hr} \\
\$ / \mathrm{kWh}\end{array}$ & $\begin{array}{l}45.9 \\
0.310 \\
\end{array}$ & $\begin{array}{l}34.4 \\
0.310 \\
\end{array}$ \\
\hline \multicolumn{4}{|c|}{ Table 10: Fuel consumption } \\
\hline Quantity & Units & $\begin{array}{l}\text { Gen1 } \\
\text { Value }\end{array}$ & $\begin{array}{l}\text { Gen2 } \\
\text { Value }\end{array}$ \\
\hline Fuel consumption & $\mathrm{L} / \mathrm{yr}$ & 498,774 & 323,429 \\
\hline $\begin{array}{l}\text { Specific fuel consump- } \\
\text { tion }\end{array}$ & $\mathrm{L} / \mathrm{kWh}$ & 0.358 & 0.465 \\
\hline Fuel energy input & $\mathrm{kWh} / \mathrm{yr}$ & $4,907,938$ & $3,182,546$ \\
\hline $\begin{array}{l}\text { Mean electrical effi- } \\
\text { ciency }\end{array}$ & $\%$ & 28.4 & 21.9 \\
\hline
\end{tabular}

\subsection{Extractable power output}

The power output of the site at $70 \mathrm{~m}$ height has been calculated based on the Betz limit using the following variables: A (swept area of the chosen turbine), $\rho=1.223 \mathrm{~kg} / \mathrm{m}^{3}$ having a total power output of $2,753,266.48 \mathrm{kWh} / \mathrm{yr}$. Fig. 14 shows the chart of the monthly expected output energy.

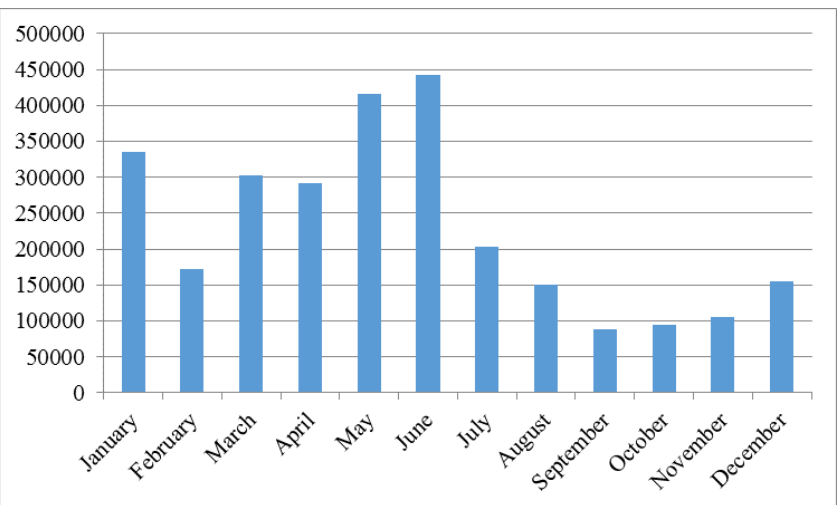

Fig. 14:3 power output based on Betz limit

The total output from this calculation shows a difference of $9 \%$ higher when compared to the simulation result values found in homer at about $25 \%$ capacity factor short of Betz limit. This drop is because, in practice, the extractable power by the rotor is less than the Betz limit due to electrical losses, mechanical losses, and aerodynamic losses $\left(0.2<\mathrm{C}_{\mathrm{P}}<0.5\right)$ [14]. However, it is imperative to note that if the wind blows at twice its initial speed, then its energy production will increase 8 -fold. For instance, a turbine at a site where the wind speed averages $8 \mathrm{~m} / \mathrm{s}$ will produce around $80 \%$ more electricity than a site with wind speed of $6 \mathrm{~m} / \mathrm{s}$ [2].

\subsection{Economics result}

The design examines the viability of the power system with regards to total net present cost of the system and the levelized cost of energy. The result indicates that the system have a net present cost of $\$ 10,769,330$ and a levelized cost of energy of $\$ 0.279 / \mathrm{kWh}$ as shown in table 12 .

Table 12: Cost summary

\begin{tabular}{|l|l|}
\hline Total net present cost & $\$ 10,769,330$ \\
\hline Levelized cost of energy & $\$ 0.279 / \mathrm{kWh}$ \\
\hline Operating cost & $\$ 1,013,011 / \mathrm{yr}$. \\
\hline
\end{tabular}

The cash flow of the power system components used as well as the breakdown of their costs are as shown in Fig. 15 and 16 respectively.
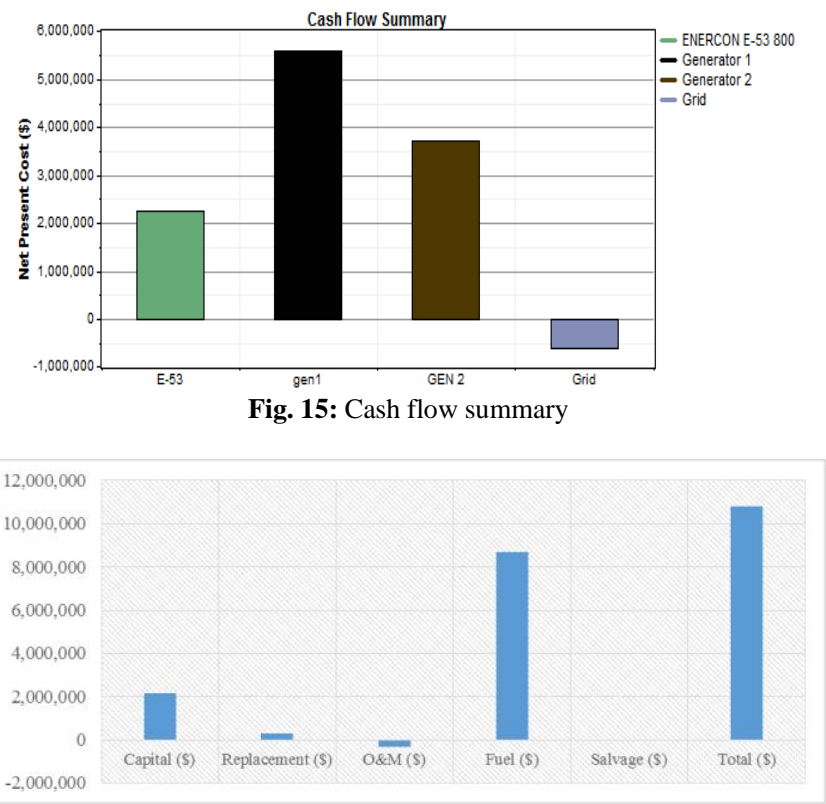

Fig. 16: System cost

It can be seen from Fig.16 that the fuel cost contributes significantly to the total cost of the system.

The COE of the wind/diesel power system was compared with standalone diesel power system as well as the cost of electricity from the grid. Fig. 17 illustrated that the designed power system has higher COE of about $180 \%$ in comparison with the cost of the energy obtainable from the grid in Nigeria and almost $40 \%$ less than that of standalone diesel system.

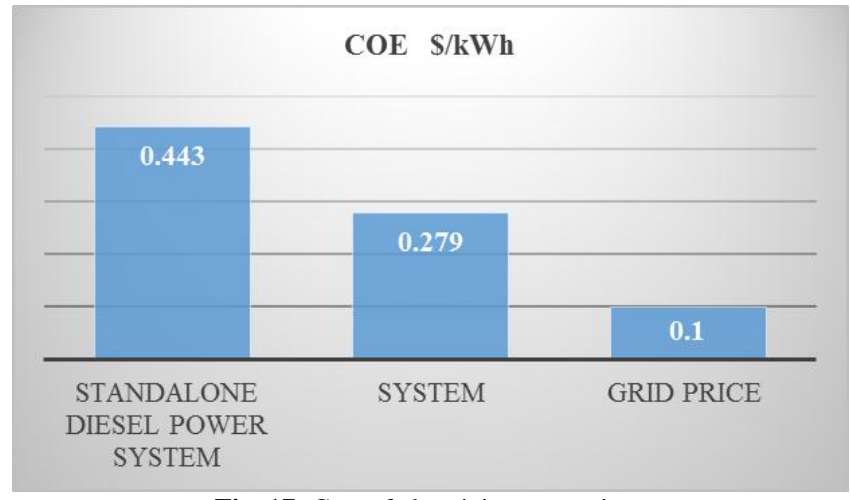

Fig. 17: Cost of electricity comparison

The value is high based on the fact that Nigeria has one of the lowest net electricity generation per capita rates in the world. Meanwhile, it is important to note that the grid is not supplying the stable power that meet the demand of the general public. As such, the system may be considered satisfactorily reliable and viable since it meet the load demand of the site adequately.

It can be seen that the wind power has a very fair cost of electricity $(0.108 \$ / \mathrm{kWh})$ and this has contributed greatly to the fall in the cost of energy of the entire system, going by the COE $(\$ 0.443 / \mathrm{kWh})$ of the standalone diesel generators system. The penetration of the wind power has impacted positively to the modelled power system by providing savings of about 403,300L/yr. which worth up to $\$ 500,000$ in monetary value. A higher value of fuel price affects the cost of energy and net present cost of the whole system, but does no effect to the way the chosen system architecture was selected. The system may, therefore, be cheaper when the cost of fuel falls and becomes expensive whenever the fuel prices goes up as seen from the sensitivity tables. 


\section{Conclusion}

A power system was modelled using various input parameters with a winner design consisting of a single wind turbine of $800 \mathrm{~kW}$ capacity combined with two generators of $400 \mathrm{~kW}$ and $300 \mathrm{~kW}$ to serve average load demand of $10000 \mathrm{kWh} /$ day. The system has an NPC value worth around $\$ 110000$ with a COE of $\$ 0.279$. The system is a grid tie selling about $18 \%$ of its total electricity production to the grid and consuming the remaining $82 \%$ onsite. The system is sized by considering different options of wind turbines capacity and generators. The result shows that the system has high cost of energy as compared to grid; but more viable than the diesel power station alone. The system will save about 480,000 litre of fuel per year.

\section{Acknowledgement}

I will like to express my appreciation Prof. D. Swift-Hook for his immense contribution towards the success of this research. My sincere thanks goes to Senator Usman Bayero Nafada for sponsoring the research. Finally, I want to send my gratitude to Abubakar Tafawa Balewa University Bauchi. My sincere appreciation also goes to TETfund for sponsoring the conference.

\section{Reference}

[1] Swift-Hook, D., "History of Wind Power" In: Comprehensive Renewable Energy,. Oxford: Elsevier, 2012, pp. Vol 2, pp. 41-72.

[2] Sahin, A. D., "Progress and recent trends in wind energy" Progress in Energy and Combustion Science, 2004, pp. 501-543.

[3] National Population Commission Nigeria (NPC) 2018. [Online] Available at: http://www.population.gov.ng/index.php/84news/latest/106-nigeria-over-182-million-population-implicationsand-challenges [Accessed 1506 2018].

[4] Enertech,. "End-use Metering Campaign for Residential Houses in Nigeria: Metering Campaign Report", Energy Commission of Nigeria, Federal Ministry of Environment, United Nations Development Programme, Global Environment Facility, 2013

[5] Gaines, D. J., "Overview on Renewable Energy Projects, Feed in Regulations and Solar Energy in Nigeria". S.1.:Gaines Consulting, 2013

[6] EMD, 2014. EMD WindPro. [Online] Available at: http://www.emd.dk/WindPRO/Modules/ [Accessed 0107 2014].

[7] www.skyscrapercity.com, 2014. skyscrapercity. [Online] Available at: $\quad$ http://www.skyscrapercity.com/showthread.php?t=1649234 [Accessed 1208 2014].

[8] Shaaban, M. \& Petinrin, J. O., "Renewable Energy Potentials in Nigeria: Meeting Rural Energy Needs" Renewable and Sustainable Energy Reviews, 2014. pp. 72-84.

[9] Suberua, M. Y. et al., "Power sector renewable energy integration for expanding access to electricity in sub-Saharan Africa" Renewable and Sustainable Energy Reviews, 2013, pp. 630-642.

[10] Moghavvemia, M. et al., "Development and optimization of a PV/diesel hybrid supply system for remote controlled commercial large scale FM transmitters" Energy Conversion and Management, 2013, pp. 542-551.

[11] Hu, Y. \& Pablo, S., "Optimization of a hybrid diesel-wind generation plant with operational options" Renewable Energy, 2013, pp. 364-372.

[12] Lambert, T., "Micropower System Modeling With Homer" Integration of Alternative Sources of Energy. S.1.:John Wiley \& Sons, Inc., 2006, pp. 379-418.

[13] Nuhu Mohammed, "Analysis of Wind Energy Potential in Kano Nigeria Using WindPRO: A Case Study of Kwankwasiyya City" International Journal of Engineering Research \& Technology, Vol. 6 Issue 03, March-2017, pp.553-559

[14] Patel M. R., "Wind and Solar Power Systems" New York: CRC Press, 1999

[15] Mamatha Sandhu, Tilak Thakur "Issues, Challenges, Causes, Impacts and Utilization of Renewable Energy Sources - Grid Integration" Int. Journal of Engineering Research and Applications Vol. 4, Issue 3 (Version 1), March 2014, pp.636-643
[16] C. L. Anderson and J. Cardell, "Analysis of wind penetration and network reliability through monte carlo simulation" Simulation Conference (WSC), Dec. 2009, pp. 1503-1510.

[17] H. Ibrahim, M. Ghandour,, M. Dimitrova, A. Ilinca, J. Perron "Integration of Wind Energy in to Electricity Systems: Technical Challenges and Actual Solutions" Energy Procedia 6 (2011) 815824 